Copyright (C) 2016 by Academic Publishing House Researcher

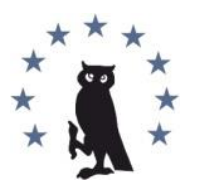

Published in the Russian Federation

European Researcher

Has been issued since 2010.

ISSN 2219-8229

E-ISSN 2224-0136

Vol. 105, Is. 4, pp. 216-230, 2016

DOI: 10.13187/er.2016.105.216

www.erjournal.ru

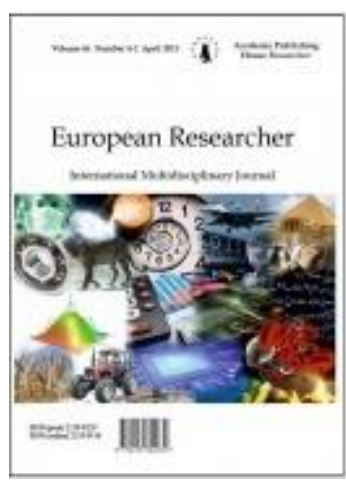

UDC 37

\title{
The Image of the White Movement in the Russian Feature Cinema at the Present Stage (1992-2016)
}

Alexander Fedorov

\author{
Anton Chekhov Taganrog Institute, \\ branch of Rostov State University of Economics, Russian Federation \\ Dr. (Pedagogy), professor \\ E-mail: mediashkola@rambler.ru
}

\begin{abstract}
This article gives the way for hermeneutic analysis of the topic of the White movement in the mirror of the Russian cinema at the present stage (1992-2016). The hermeneutical analysis suggests media text comprehension through comparison with historical, cultural tradition and reality; penetration of its logic; through comparison of media images in historical and cultural context by combining historical, hermeneutical analysis of the structural, plot, ethical, ideological, iconographic / visual, media stereotypes and analysis of media text characters. An analysis of this kind of media texts, in our opinion, is particularly important for media literacy education of future historians, culture and art historians, sociologists, psychologists and educators. Thus, the comparative analysis of plot schemes, characters, and ideology of the Russian feature films of 1992-2016, in varying degrees of affecting the subject of the White movement, leads to the conclusion about the essential similarity of their media stereotypes. Content analysis of screen media texts of 1992-2016 on the topic related to the White movement allows generally to submit their basic narrative schemes.

Keywords: White movement, Russian cinema, films, hermeneutical analysis, Russia, film studies, media texts, media literacy.

\section{Introduction}

Thus, the research problem stems from the contradiction between the relatively more scientific designed ideological, political science and historical aspects of the Civil War and the movement of the White associated with it and also insufficient attention of scientists to the evolution of the image of the White movement in the cinema.

Studies Russian film researchers were still focused on the traditional "historicalrevolutionary", "heroic and patriotic", military, etc. topics. For example, in this way it was analyzed films of the 1960s-1970 in the writings of Film "conservative" school stood on the positions of the so-called "socialist realism". This topic is not considered separately and in the works of the famous Russian historians and theorists of cinematic art "liberal" direction 1950s-1990s (V. Demin, N. Zorkaya, K. Razlogov, M. Turovskaya). Thus, it seems to be urgent to explore, organize, and analyze the evolution of interpretations of the theme of the White movement in the film industry,
\end{abstract}


taking into account the socio-cultural, political and ideological context of typology of plot diagrams and characters in the movie, the key concepts of copyright, etc.

\section{Discussion}

Among all the Russian films about the White movement, shot in the modern times, the most notable discussion revolved around the melodrama Admiral (2009) by A. Kravchuk and drama Sunstroke (2014) by N. Mikhalkov. Although, in my opinion, drama Fascination of Evil (2006) by M. Kazakov deserved such a discussion and it was obviously underestimated (by as the audience so the film critics).

The most ardent opponents of the Admiral, speaking about the latest romantic love of one of the leaders of the White movement A.V. Kolchak (1874-1920), were ruthless, claiming that the authors of the film "on top of the computer shooting pasted the melodrama in which all mental anguish are illustrated by the same expression on the doll lovers little face of the heroine. Because the Civil war was waged by icon painting White officers and against them "something," that with the brutal face, blowing his nose with one finger, cuts of any innocent people" [Smirnov, 2008].

Around the same spirit pro-Soviet critics responded to the Admiral, emphasizing that the Admiral, where "there are ripples in the eyes from the Russian banners, icons and high-flown words about the glory of the Fatherland, he destroys the firstborn understanding of social justice, as there is no hero commoner in the film - there are only "noble" gentlemen officers. Common people in the film are shown as a murderer, (in the image of the Bolshevik sailors), or as a faceless mass, cannon fodder, whom these officers lead to the attack with the help of bayonets for victory. .... There is no in them, and apparently never will be their adjutants of his excellency, where Whites and Reds were presented with the objective position when the bloodshed by both sides would be divided equally. Instead of it, in the new Russian cinema Whites assigned the role of noble fighters for bright idea of light, and Reds assigned the role of brutalized cattle, which deserve nothing except the bullet" [Razzakov, 2008].

It seems to me that in this dispute I.E. Petrovskaya is right. She wrote that in the melodramatic Admiral "everything is clear and certain: there is the main character without fear and reproach - he is beautiful, courageous, brave, smart, played by a favorite of the public Constantine Habensky. There is a heroine beloved hero - she is beautiful, feminine, sacrificial and elegant - in the performance of public favorite Elizabeth Boyarska. There is another character, she is Kolchak's wife - she is beautiful, feminine, loyal and also very elegant - in the performance of another audience favorite Anna Kovalchuk. There are valiant Russian officers - they are beautiful, noble and courageous, in the gold of epaulettes. In general, they are all handsome, all heroes, all of them poets - and almost all cause sympathy in contrast to their opponents, Reds, which in fact can be any color, because the main thing in them is that they are not Reds but that against them for the great motherland such nice heroes fight. There is no any special psychology in Admiral. But audience loves to watch costumes and a love story against the backdrop of the war, adding a love story sharpness and dramatic" [Petrovskaya, 2009].

To put it most generally, the key questions to the authors of Sunstroke were: "What kind of Russia did we lose? How and why did it happen?".

It is clear that a liberal media critics shop sharpened the long teeth on N. Mikhalkov and his work in general it treated sharply negative to his Sunstroke, put on the works of Nobel laureate I. Bunin (1970-1953). Among the most common words used in reviews as guilty, "poster", "heaviness", "banality", "arrogance", "nationalism", "anti-Darwinism", "monarchism", "heaviness", "strained", "weakness", "slowness", "boredom", "illustrative", "tastelessness", "vulgarity", "dishonesty", "false", "anti-liberal propaganda", "compulsive self-citations", etc. [Bezrukov, 2014; Bogomolov, 2014; Gireev, 2014; Gladilschikov, 2014; Zabaluev, 2014; Zelvenskiy, 2014; Ivanov, 2014; Matizen, 2014; Maslova, 2014; Plakhov, 2014; Solntseva, 2014; Tyrkin, 2014].

One of the main arguments against the author's concept of Sunstroke became the liberal accusation to N. Mikhalkov that he in his films of the 1970s was for Reds, and now - for Whites, but always - he was on the side of "The Authorities which was given by God" [Kichin, 2014; Matizen, 2014; Pavlyuchik, 2014]. Of course, some of the liberal critics' community did not escape the temptation to "go to person", accusing N. Mikhalkov in loss of his former artistic forms that they once admired [Kudryavtsev, 2014; Stishova, 2014]. 
However, among the critics of the liberal wing there were also those who were bored to assess the ideology and philosophy of the authors of Sunstroke, because they did not see in him any artistic merit [Zelvenskiy, 2014].

And it is quite radical in its desperate sense of primitivism of Sunstroke belongs, probably, to D. Bykov: "Mikhalkov is in the "strike", pardon the pun involuntary, supposed to sound stern warning - it is necessary, they say, time to eliminate the enemies, not to spare, drop any indulgence - the children, they say, freedom of speech, they say - and today it is necessary to do everything in order Russian events of 1917 wouldn't find any repetition" [Bykov, 2014].

As a result, it seems, the only discordant note in the consolidated opinion of the liberal media criticism became a replica of A. Dolin: Sunstroke of three hours of emptiness and what is it all about? "Talk about the inability of the unit to the analysis, I'm sorry. The essence of the film is simple and clear, it is formulated in two words: Russian Titanic. A story of fleeting love on a ship and a shipwreck at the end means deluge, the end of the world, and the punishment for sins. It is the whole structure and distinct idea, which is hard to argue" [Dolin, 2014].

Admirers of N.Mikhalkov from the ranks of the conservative critics in relation to Sunstroke and its creators actively used the complimentary words and phrases: "perfect", "great", "cinema event", "skill", "artist", and others. [Vladimirov 2014; Danlova, 2014; Moskvina, 2014; Ometsinskay 2014; Surikov, 2014; Yampolskaya, 2014].

In response to many of the cited above reproach liberals, the conservative wing media criticism confidently argued that Sunstroke - is not propaganda, but complex and multi-valued work of art [Ometsinskaya 2014; Rutkovsky, 2014; Surikov, 2014; Tolkunova, 2014; Haknazarov, 2014].

Then all went here E. Yampolskaya: analyzing the actions of the characters of Sunstroke, she urged the audience for the prescription of years to rise above the fray of Reds and Whites, "because in the civil wars there are no any heroes, there are only the victims": "In Sunstroke there are no abuses of Reds - Mikhalkov is not working frontally. ... There is also no the idealization of White officers. All are people, all are different. ... Russia was slept like a beloved woman. When they woke up - she had disappeared behind a bend. Who is now blamed? Whom will we go there? There are only ourselves. Blacks are accumulated in the emotional holds there is the intoxication of desperate hatred. One from the cowardice passed a restless captain to the Bolsheviks; another intelligently and coolly strangled a traitor. Not from the suitcase there is a trail of blood on his hands" [Yampolskaya, 2015].

So, being in the mirror of Russian media criticism, Admiral and Sunstroke, in fact, has become an indicator of the political separation of critical plant: in many cases, these films were analyzed in the first place, not as a work of art, but as social, ideological statements. However, this is not surprising, because for the stratification among critics stands the stratification of audience. However, the Russian mass audience as a whole is much more conservative than film critics' community. And, of course (as eloquently the modest box-offices of Sunstroke and very impressive of Admiral say), it is more focused on a bright and spectacular component of media culture.

In a few Russian films at the beginning of the XXI century there was an attempt of a balanced, conciliatory towards the Reds and Whites approach. Red and White characters of dramas Kromov (2009) by A. Razenkov, Isaev (2009) by S. Ursulyak, The purple colour of snow (2010) by V. Motyl, Eye for an Eye (2010) by G. Poloka has their own truth, and the directors did not seek to clear indictment accents ... Approximately the same position was taken by the creators of the series Wolf Sun (2014), where with the same sympathy were portrayed as White Guard general so the spy of Reds, made his way to his camp.

\section{Results}

\section{The total socio-cultural, political and ideological context of the 199os:}

- The fall of prices in oil and the crisis of the inefficient state economy, led to the financial, food and commodity collapse to the beginning of the 1990s, to the attempt of conservative state coup in the summer of 1991 and to the disintegration of the USSR in December of 1991;

- An official condemnation of the communist ideology and mass repressions. The rehabilitation of millions of innocent prisoners and dissidents who were shot and repressed;

- A course for the abolition of censorship restrictions and the free exchange of people and ideas from the West; 
- The beginning of economic reforms, the revival of private property, "shock therapy"; a sharp division of society into the few rich and the broad masses of the population who is at risk of poverty;

- The attempt of illiberal state coup in the autumn of 1993;

- Crisis in the movement of reform, the war in Chechnya, the solution of economic problems with the help of the West loans, the decline of the Russian industry, including film production;

- Russian financial default of 1998.

At these stages at the actual abolition of censorship authors of Russian media texts for the first time of many decades had the opportunity to address the most acute, first having taboo subjects, including the themes of violence, mass terror (including the era of the Civil War) and the repression of the communist regime. The concept that the era of terror and violence of the revolution and the Civil War as a fratricidal war itself have been a tragedy of the Russian people it was dominated on the screen.

At this stage, there is an increasing product where violence and terror of the civil war are brought as the inhuman, inhumane methods. There were created movies, condemning both mass and individual terrorism with someone side it has not been used...

As about the style of movies related to the topic of the White movement, in addition to traditional realism (And Quiet Flows the Don by S. Bondarchuk, Trotsky by L. Maryagin, etc.) it was made grotesque, ironic movies (Return of the Battleship by G. Poloka).

Genre modification: it's a drama (military, historical), action or detective.

The prevailing models of the films about the Civil War:

- Mass terror during the Civil War, as well as the terror of the communist regime against its own citizens deforms the human personality, turns people into torturers and victims - "cogs" of totalitarian dictatorship (Wolf Blood, Trotsky, White horse, etc.);

- "Revolutionary terror", "ideological terror" involves, first of all, people with aggressive tirst for power, types of people with mental disorders, who somehow want to leave a blood trail in the history (Regicide, Chekist, Trotsky, etc.);

At this stage, there are increasing of products where terror during the Civil War and Revolution is categorically rejected as inhuman. There are created movies, condemning both mass and individual terrorism with someone side it has not been used...

For example, in western Wolf blood by N. Stambula, which takes place in the era of the Civil War, he tried to escape from the definitive characteristics. His Reds are not angels, but those who are against them, too, without a halo over his head. War is shown as a cruel and bloody and largely meaningless confrontation of strong men. Another thing was that the film was made without the glitz and comparison with a dashing and stylish movie Among strangers... by Mikhalkov.

But Boris Blank in search of spectacular material for the topic of confrontation of Reds and Whites referred to the works of A.P. Chekhov which were far away from that kind of problems. Well, the free fantasy on the theme of famous classical works of art is quite usual in practice. For example, someone is not only appeared as Hamlet on stage and screen of the last decades: he was the masochist, and erotomania, and adept of the blue love... So in that sense, the film If only we know ... (1993) by Boris Blank, staged on the grounds of play Three Sisters (1900) by Anton Chekhov, is not exactly avant-garde phenomenon. Another thing is that the domestic censorship of previous years such kind of experiments with the classics were not allowed, and in the 1990s, as they say, was allowed all ...

The action of the film by Boris Blank takes place in the summer of 1918 at the station of the southern town of N., where three sisters and other Chekhov's characters find themselves. The decadent theatrical action is unfolded on the screen under the melody of Peter Leshchenko and Alexander Vertinsky. One of the sisters is a lesbian, the other like a cat is in love with his pupil, schoolboy, due to which it becomes a victim of gang rape... In short, the filmmakers are doing everything in their power that the intelligent Chekhov's characters will appear on the screen telling the epitome of evils and at best will be pathetic mixed with disgust, and the rhymes of atmosphere of collapse on the turn of the 1920 s and 1990 s would be noticeable even the most sophisticated viewer ...

To remove a stylish kitsch, it is necessary to have the talent of Pedro Almodovar, or even to rise to the level of House under the stars (1991) by Sergei Solovyov. Stylish kitsch suggests cinema going visuality, virtuosity of installation, subtle sense of parody, ironic and detached play of actors, 
which, however, is not in the movie by Boris Blank, where eroticized characters casually recite the famous Chekhov's replicas. Undoubtedly, Boris Blank is a gifted artist on whose sketches the iconic world of famous films by Elem Klimov, Alexander Mitta and Emil Lotyanu were created, and in his work as a director, he was able to show off the skill of creating the interiors and decorations. But the advantages of the film If only we knew ... it seems to me, are limited.

As for the immediate rehabilitation of the White movement, then perhaps its first cinematic attempt was made in the film White Horse (1993) by G. Ryabov, where a positive image of Admiral A.V. Kolchak appeared the first in the Russian film.

\section{The structure of the stereotype image of the White movement in the Russian cinema of the 1990 s}

\section{Russia.}

historical period, the place of action: it is any period of time from 1918 till 1924,

furnishings, household items: the modest dwelling, uniform and everyday objects of Red characters, neat houses, the uniform and household items of White characters (especially - the high command).

methods of depicting reality: realistic (And Quiet Flows the Don) or conditional - in the framework of the western (Wolf blood) image of the life of characters of the White movement.

characters, their values, ideas, clothes, physique, vocabulary, facial expressions, and gestures: Red and White characters are differentiated: on the one hand, these are negative characters that support the inhumane ideas, on the other hand - these are people who defend their principles and ideas of honor, good and evil. Characters are shared by not only social, but also material status. Whites are dressed as a rule, richer and humble than poor Reds. As for the body, there is allowed options - Whites on the screen (depending on the task) are the subtle or intellectuals or athletic looking men.

These White characters are shown not only rude and cruel enemies, with a repulsive appearance, facial expressions and gestures domineering and unpleasant voice timbres, but also subtle and charming beauties with impeccable manners and refined vocabulary.

Male characters, personified the White movement, still dominated above a significant change in the lives of the characters: negative characters (both Reds and representatives of the White movement) through violence and fraud are going to implement their ideas.

Option: intelligent charming characters from the circle of the White movement are drawn into the revolutionary events in the maelstrom of civil war and try to keep their romantic value.

a problem: the life of Red and White characters, for that matter, and the existence of the state as a whole are at risk: at risk is charming and intelligent life characters who are trying to maintain neutrality.

the search for solution to the problem: the struggle (various types and methods) of Red and White characters; hesitations of charming intelligent characters.

solution to the problem: the conscious destruction / arrest of Red or White characters; destruction / arrest hesitated / or intelligent, romantic Whites characters.

Russian brothers. Russia, 1992. Directed by N. Fomin. Drama.

historical period, the place of action: civil war, the former Russian empire.

furnishings, household items: the White Guard detachment in the vicinity of the convent, the modest life of characters of all categories.

methods of depicting reality: quasi realistic.

characters, their values, ideas, clothes, physique, vocabulary, facial expressions, and gestures: the characters in the film are shared by the social status. Whites are dressed richer than the poor and humble Reds. With regard to the constitution, all the male characters look strong and sturdy, worthy of each other's enemies ... These white characters (one handsome officer in the performance of V. Ivashov worth something!) are shown mainly by people with pleasant voice tones, appearance and vocabulary.

a significant change in the lives of the characters: Reds and Whites tend to beat each other.

a problem: the life of the main characters is under the threat. 
the search for solution to the problem: the main characters - each in his own way are developing plans for destruction of each other in a fratricidal civil war ...

solution: but in this fight, when his brother goes with the weapon at his brother in the end, all are doomed to failure, if not physical, moral ...

Wolf blood. Russia, 1995. Directed by N. Stanbula. Western.

historical period, the place of action: civil war, the Urals.

furnishings, household items: the Ural mountains and forests, the Red squad, the White Cossack detachment; the modest life of characters in all categories.

methods of depicting reality: quasi realistic.

characters, their values, ideas, clothes, physique, vocabulary, facial expressions, gestures: the characters in the film almost are not shared by any social or financial status (and the one and the other side are the Cossacks), and their vocabulary is little different. (for except White Guard colonel in the colorful performance of R. Adomaytis who before dying regrets only one thing: that, together with his troops fought with the Germans, and he did not open them the way to Moscow, where the bloody Bolsheviks are now). With regard to the constitution, all the male characters look strong and sturdy, worthy of each other's enemies.

a significant change in the lives of the characters: the Cossack troops are seeking to defeat one another.

a problem: the life of the main characters is under the threat.

the search for solution to the problem: the main characters - each in his own way - are developing plans for destruction of each other in a fratricidal civil war ...

solution to the problem: in this struggle, built largely by the laws of the spaghetti westerns of S. Leone, Reds luckier: they manage to destroy the enemies.

If you like to know... Russia, 1992. Directed by B. Blank (based on fragments of the play of Anton Chekhov Three Sisters). Drama.

historical period, the place of action: the Crimea of 1918.

furnishings, household items: interior station, designed in art deco style, train-station hotel rooms, a restaurant, a park, Colonnade, nice officer's uniform, elegant women's dresses.

methods of depicting reality: a quasi-realistic picture of events.

characters, their values, ideas, clothes, physique, vocabulary, facial expressions, gestures: White officers are shown ironic and tired intellectuals who are not without their perversity, they are educated, they have refined vocabulary, they have extremely negative attitude to the entire Soviet-Bolshevik (Bolsheviks themselves, Reds are not hardly shown, their negative images appear essentially only in conversations of officers).

a significant change in the lives of the characters: the representatives of the officers, the bourgeoisie and the intelligentsia cannot leave the Crimean city because of the lack of trains ...

a problem: the life of the main characters is under a potential threat to their arrest by the Bolsheviks.

the search for solution to the problem: the main characters are trying to survive by any means available to them ...

solution: a few months later it is certainly the train comes to the station..

The period of the $2000 \mathrm{~s}$

\section{The total socio-cultural, political and ideological context of the 2ooos:}

- The presidency of Vladimir Putin (including a four-year break for the presidency of D. Medvedev) with a specific vertical centralization of state power;

- The official end of the war in Chechnya;

- The increase in oil prices, which allowed, at least until the global financial crisis of 2008, the development of raw materials economy of Russia;

- The military conflict between Georgia and Russia in South Ossetia in August of 2008;

- The financial crisis of the second half of 2008 with subsequent slowdown in Russian (as, indeed, the world) economy; 
- Political and economic problems of 2014-2016 associated with the state coup in the Ukraine, entrance of the Crimea to Russia, the civil war in the Donbass, the sharp fall in oil prices in the autumn of 2014 and the mutual sanctions between Russia and the West of 2014-2016.

The line for the rehabilitation of the White movement (already indicated in the 1990s) was continued in Russian cinema 2000 .

It was mostly the work of traditional realism (The Romanovs - Crowned Family by G. Panfilov, Doctor Zhivago by A. Proshkin, Fascination of Evil by M. Kazakov, Isayev by S. Ursulyak, The White Guard by S. Snezhkin, The purple colour of snow by V. Motyl, An eye for an eye by G. Poloka and others.).

Genre modification also continued the baton of 1990s: drama (military, historical), action and detective.

The prevailing model of the film of the 20oos about the Civil War:

- Mass terror during the Civil War, as well as the terror of the communist regime against its own citizens, deformed human personality, turning people into torturers and victims - "cogs" of totalitarian dictatorship (The Romanovs - Crowned Family, Fascination of Evil, Admiral, Doctor Zhivago, The purple colour of snow, etc.);

- "Revolutionary terror", "ideological terror"... First of all it is the good chance for people with aggressive love to power, the types with mental disorders, who somehow wants to leave a trail of blood in the history (The Romanous - Crowned Family, Nine Lives of Nestor Makhno);

- The faith and the truth are on the side of the Whites in the fight of Reds and Whites, but due to a number of circumstances, they still lost (Admiral, Gentlemen Officers: Save the Emperor, The White Guard, Steep mountains).

\section{The structure of the stereotype image of the White movement in the Russian cinema of the $2000 \mathrm{~s}$} Russia.

historical period, the place of action: any period of time from 1918 till 1924 years,

furnishings, household items: the modest dwellings, uniform and everyday objects of Red characters, neat houses, the uniforms and household items of Whites characters (especially the high command).

methods of depicting reality: it is a realistic (Doctor Zhivago, Fascination of Evil, Isayev, And Quiet Flows the Don, The purple colour of snow, The White Guard, Sunstroke) or conditional (Chapaev Chapaev, Gentlemen Officers: Save the Emperor) image of characters life of the White movement.

characters, their values, ideas, clothes, physique, vocabulary, facial expressions, gestures: Red and White characters are differentiated: on the one hand, these negative characters are inhumane ideas (in the films of the 2000s these are basically Reds), on the other hand - these are people who defend their principles and ideas of honor, good and evil (the representatives of the White movement). Characters are shared not only by social, but also by material status. Whites were dressed richer than the poor Reds. As for the body, there is allowed options - Whites on the screen (depending on the task) are either intellectuals or athletic looking men. Reds on the contrary, are rude and violent, with a repulsive appearance, facial expressions and gestures domineering and unpleasant voice tones. Male characters, personified the White movement, continue to dominate.

a significant change in the lives of the characters: the negative Red characters through violence and fraud are going to implement their ideas. Option: intelligent charming characters from the circle of the White movement are drawn into the revolutionary events in the maelstrom of civil war and try to keep their romantic value, partly trying to understand 'Red truth'.

a problem: the life of Red and White characters, for that matter, and the existence of the state as a whole are at risk: charming and intelligent life characters who are trying to remain neutral is at risk too.

the search for solution to the problem: the struggle (various types and methods) of Red and white characters; fluctuations of charming intelligent characters.

solution to the problem: the conscious destruction / arrest of Red or White characters; destruction / arrest of oscillating / or intelligent, romantic White characters. 
Examples:

Admiral. Russia, 20o8. Directed by A. Kravchuk. Melodrama.

historical period, the place of action: the civil war, the former Russian empire.

furnishings, household items: the modest dwellings, uniform and everyday objects of Red characters, neat houses, the uniform and household items of White characters (especially - the high command).

methods of depicting reality: conventional (within the romantic melodrama) image of characters life.

characters, their values, ideas, clothes, physique, vocabulary, facial expressions, and gestures: Red and White characters are shared by the social and material status. Positive characters (representatives of the White movement) - are the carriers of positive ideas of Russia's revival, a personification - is Supreme Ruler of Russia Admiral A.V. Kolchak (1874-1920), a charming and intelligent man, honestly and courageously stands up for his principles and ideas of honor, good and evil. He has excellent military bearing, good manners and refined vocabulary. Red characters - are on the contrary, brutalized, with repulsive looks, facial expressions domineering and unpleasant voice tones.

a significant change in the lives of the characters: the negative Red characters through violence and fraud are going to realize their communist ideas. The positive characters representatives of the White movement, headed by Admiral A.V. Kolchak stand up for the values of one and indivisible Orthodox Russia, organizing armed resistance to the Bolsheviks.

a problem: during the Civil War the life of positive characters are under a potential threat.

the search for solution to the problem: in a hard struggle with the Bolsheviks Admiral A.V. Kolchak tries to enlist military support of the Western allies.

solution to the problem: Western allies actually betray A.V. Kolchak, in battles with the troops of the Reds his Army takes a beating, A.V. Kolchak is captured, he is judged, and February 7 , 1920 he is shouted.

Gentlemen Officers: Save the Emperor. Russia, 2008. Directed by O. Fomin. Action.

historical period, the place of action: the summer of 1918, the Civil War, the former Russian empire

furnishings, household items: effect of genre features of a movie that mostly takes place in nature, there is no emphasis on housing and household items of Whites and Reds: and they both dressed in military / paramilitary form, those and others have weapons.

methods of depicting reality: it is conventional (within the genre thriller) image of characters life.

characters, their values, ideas, clothes, physique, vocabulary, facial expressions, and gestures: Red and White characters are shared by the social and material status. Positive characters (representatives of the White movement) are the carriers of positive ideas of Russia's revival and salvation of the Emperor Nicholas II and his family captured by the Bolsheviks. This charming people, honestly and courageously defending their principles and ideas of honor, good and evil. They have excellent military bearing, pleasant appearance. Red characters are on the contrary, rude and violent, with a repulsive appearance.

a significant change in the lives of the characters: the negative Red characters through violence and fraud are going to realize their communist ideas, they are arrested and remanded the arrest of the royal family in Yekaterinburg. The positive characters - representatives of the White movement - decide to release the emperor and his family.

a problem: the life of the positive character is under the threat.

the search for solution to the problem: a detachment of officers make plan to release the royal family and tries to carry it out.

solution to the problem: in spite of the heroism of the White movement, which they had shown in the fight against the Reds, they still cannot save the royal family and the emperor himself from execution 
Isaev. Russia, 2009. Directed by S. Ursulyak (screen version of Y. Semenov' novels). Drama.

historical period, the place of action: civil war, the Far East early 1920 .

furnishings, household items: the modest dwellings, uniform and everyday objects of Red characters, neat houses, the uniform and household items of White characters (especially - the high command).

methods of depicting reality: (quasi)realistic.

characters, their values, ideas, clothes, physique, vocabulary, facial expressions, gestures: the characters in the film almost are not shared by any social or material status: Red spy Isaev comes from the same environment as the representatives of the Far East of the White movement; and their vocabulary is little different. White characters look worthy opponents of Isayev. ...

a significant change in the lives of the characters: Whites and Reds tend to beat each other in the fight for the Far East.

a problem: the life of Red and White characters is under the threat.

the search for solution to the problem: the protagonist of the film Isaev tries to fulfill his mission, and the white counter-intelligence tries to do the same .

solution to the problem: White movement and their allies defeat the Japanese in the Far East, which becomes the part of Soviet Russia...

\section{Conclusion}

Thus, our analysis showed that all - in USSR / Russia and abroad - from 1931 to 2015 it was filmed 297 movies, anyway affect the subject of the White movement. In the genres attitude clearly dominated the drama (208), and then were: action (35), detective (18), romance (12), western (10), comedy (9). Naturally, the majority of these films were placed in the Soviet period: 259 films, including 179 dramas, 34 actions and 16 detectives, 9 melodramas, 9 westerns, 8 comedies. At the same time significantly (Table 1) beginning since the middle of 1960 s, the topic of the civil war in the Soviet cinema more often was given into the entertainment perspective, about which the growing number of actions, detectives and westerns became evident. During 1992-2015 years the theme of the White movement found its implementation only in 38 films, 29 of which were dramas.

Table 1: The figures for the production of Soviet, Russian and Western feature films related to the topic of the White movement (1931-2015)

(Compiled by Alexander Fedorov)

\begin{tabular}{|c|c|c|c|c|c|c|c|c|}
\hline \multicolumn{9}{|c|}{ The Soviet period } \\
\hline \multirow{2}{*}{$\begin{array}{l}\text { Year of the } \\
\text { film: }\end{array}$} & \multirow{2}{*}{$\begin{array}{l}\text { The number of } \\
\text { feature films } \\
\text { related to the topic } \\
\text { of the White } \\
\text { movement }\end{array}$} & \multicolumn{7}{|c|}{ distribution offilms by genre: } \\
\hline & & 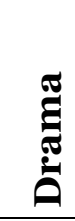 & 苞 & 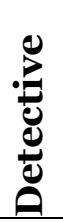 & 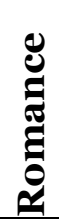 & $\begin{array}{l}\frac{1}{0} \\
\frac{1}{0} \\
3 \\
3\end{array}$ & 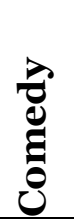 & 这 \\
\hline 1931 & 1 & 1 & & & & & & \\
\hline 1932 & 3 & 2 & & & 1 & & & \\
\hline 1933 & 4 & 4 & & & & & & \\
\hline 1934 & 5 & 5 & & & & & & \\
\hline 1935 & 3 & 3 & & & & & & \\
\hline 1936 & 4 & 3 & & & & 1 & & \\
\hline 1937 & 6 & 5 & & & 1 & & & \\
\hline 1938 & 7 & 6 & 1 & & & & & \\
\hline 1939 & 4 & 3 & & & 1 & & & \\
\hline 1940 & 2 & 2 & & & & & & \\
\hline 1941 & 2 & 2 & & & & & & \\
\hline
\end{tabular}




\begin{tabular}{|c|c|c|c|c|c|c|c|c|}
\hline 1942 & 5 & 3 & 1 & & 1 & & & \\
\hline 1948 & 1 & 1 & & & & & & \\
\hline 1951 & 1 & 1 & & & & & & \\
\hline 1953 & 2 & 2 & & & & & & \\
\hline 1954 & 3 & 2 & & 1 & & & & \\
\hline 1956 & 6 & 5 & & & 1 & & & \\
\hline 1957 & 5 & 4 & & & & 1 & & \\
\hline 1958 & 11 & 10 & 1 & & & & & \\
\hline 1959 & 3 & 2 & & & & & 1 & \\
\hline 1960 & 2 & 2 & & & & & & \\
\hline 1961 & 2 & 2 & & & & & & \\
\hline 1963 & 5 & 4 & & 1 & & & & \\
\hline 1964 & 4 & 1 & 1 & & 1 & & & 1 \\
\hline 1965 & 10 & 7 & 1 & & 1 & & 1 & \\
\hline 1966 & 3 & 1 & 1 & & & & 1 & \\
\hline 1967 & 16 & 11 & 1 & 2 & & & 2 & \\
\hline 1968 & 9 & 6 & 2 & 1 & & & & \\
\hline 1969 & 6 & 3 & 1 & 1 & & & & 1 \\
\hline 1970 & 8 & 6 & 1 & 1 & & & & \\
\hline 1971 & 12 & 7 & 1 & & 1 & & 2 & 1 \\
\hline 1972 & 2 & 1 & 1 & & & & & \\
\hline 1973 & 8 & 5 & 2 & 1 & & & & \\
\hline 1974 & 3 & 2 & & & & 1 & & \\
\hline 1975 & 9 & 5 & 1 & 1 & 1 & 1 & & \\
\hline 1976 & 7 & 7 & & & & & & \\
\hline 1977 & 8 & 6 & & 1 & & 1 & & \\
\hline 1978 & 6 & 2 & 2 & 1 & & 1 & & \\
\hline 1979 & 5 & 3 & 1 & 1 & & & & \\
\hline 1980 & 7 & 4 & 2 & & & 1 & & \\
\hline 1981 & 10 & 3 & 3 & 2 & & 2 & & \\
\hline 1982 & 6 & 5 & 1 & & & & & \\
\hline 1983 & 9 & 5 & 3 & & & & 1 & \\
\hline 1984 & 5 & 1 & 3 & 1 & & & & \\
\hline 1985 & 6 & 4 & 1 & 1 & & & & \\
\hline 1986 & 3 & 1 & 2 & & & & & \\
\hline 1987 & 6 & 5 & & & & & & 1 \\
\hline 1988 & 2 & 2 & & & & & & \\
\hline 1990 & 2 & 2 & & & & & & \\
\hline $\begin{array}{c}\text { Total for } \\
\text { the Soviet } \\
\text { period }\end{array}$ & 259 & 179 & 34 & 16 & 9 & 9 & 8 & 4 \\
\hline \multicolumn{9}{|c|}{ Russian period } \\
\hline \multirow{2}{*}{$\begin{array}{l}\text { Year of the } \\
\text { film: }\end{array}$} & \multirow[b]{2}{*}{$\begin{array}{l}\text { The number of } \\
\text { feature films } \\
\text { related to the topic } \\
\text { of the White } \\
\text { movement }\end{array}$} & \multicolumn{7}{|c|}{ distribution offilms by genre: } \\
\hline & & שี & 苞 & 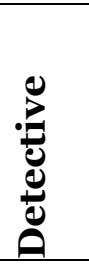 & 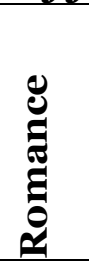 & 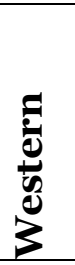 & 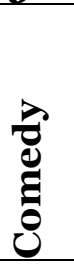 & 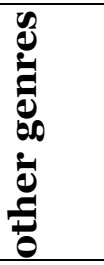 \\
\hline 1992 & 4 & 4 & & & & & & \\
\hline 1993 & 4 & 4 & & & & & & \\
\hline 1995 & 3 & $\mathbf{1}$ & & & 1 & $\mathbf{1}$ & & \\
\hline 1996 & $\mathbf{1}$ & & & & & & & $\mathbf{1}$ \\
\hline 2000 & $\mathbf{1}$ & $\mathbf{1}$ & & & & & & \\
\hline
\end{tabular}




\begin{tabular}{|c|c|c|c|c|c|c|c|c|}
\hline 2002 & 2 & $\mathbf{1}$ & & 1 & & & & \\
\hline 2005 & $\mathbf{1}$ & $\mathbf{1}$ & & & & & & \\
\hline 2006 & 2 & 2 & & & & & & \\
\hline $\mathbf{2 0 0 7}$ & $\mathbf{1}$ & $\mathbf{1}$ & & & & & & \\
\hline 2008 & 3 & $\mathbf{1}$ & 1 & & 1 & & & \\
\hline 2009 & 4 & 2 & & 1 & 1 & & & \\
\hline 2010 & 3 & 3 & & & & & & \\
\hline 2011 & $\mathbf{1}$ & $\mathbf{1}$ & & & & & & \\
\hline 2012 & 3 & 3 & & & & & & \\
\hline 2013 & 2 & $\mathbf{1}$ & & & & & $\mathbf{1}$ & \\
\hline 2014 & 2 & 2 & & & & & & \\
\hline 2015 & $\mathbf{1}$ & $\mathbf{1}$ & & & & & & \\
\hline $\begin{array}{l}\text { Total for } \\
\text { the } \\
\text { Russian } \\
\text { period }\end{array}$ & 38 & 29 & $\mathbf{1}$ & 2 & 3 & $\mathbf{1}$ & $\mathbf{1}$ & $\mathbf{1}$ \\
\hline TOTAL & 297 & 208 & 35 & 18 & 12 & 10 & 9 & 5 \\
\hline
\end{tabular}

The totalitarian regime of the Stalinist era was aware of the political and ideological importance of the topic of the civil war in the movies. And although it did not occupy a dominant place in the Soviet screen, its advocacy role has been very high. Millions of viewers (especially young) was indoctrinated the necessity of brutal acts of violence against the "class enemy", "alien elements", etc. Such films became visible base for the introduction of the mass Stalinist thesis that with the development of socialism, the class struggle must be intensified and become hardened.

Of course, this interpretation of the Civil War on the screen helped stereotyping image of "the enemy from the White Guard", which is usually attributed all sorts of negative traits (desire to return to autocracy, complete dependence on foreigners, anti-people, depravity, cruelty, terrorism, etc.). In addition, the Soviet cinema screen tried to simplify and consolidate the single term "Whites" ("White Guard") the broad spectrum of anti-Bolshevik groups - representatives of all without distinction of hostile organizations and parties (monarchist, bourgeois-liberal, democratic, socialist) and the classes and estates (nobility, clergy, bourgeoisie, prosperous peasants, a large part of the intelligentsia).

Of course, about the most severe and ruthless Red terror in the era of the Civil War (and after it) in the films of the Soviet period and it were rarely mentioned and only in a positive context - as a necessity, but the necessary opposition to all the same "white guard".

As rightly observes E.V. Volkov, "characteristic of the enemy, as a rule, is a projection of its own fears, weaknesses and complexes. If the image over time loses its credibility and power, the ideology, united society ceases its effective function. Therefore, the former state and social system enters into a period of crisis and decline" [Volkov, 2009, p.6-7].

That is why so immutable, it would seem, a negative image of the White movement, formed in the Soviet cinema of the 1930s - 1940s, gradually began to change. For example, since the middle of 1950 s, in the Soviet cinema of the civil war topic they are becoming increasingly began to rise the topic of choice of those or other characters between Reds and Whites, and the characters of the White movement is increasingly taking shape of opponents worthy of respect (Forty first, Adjutant His Excellency, There were two comrades, and others.).

This process was continued in the post-Soviet era, when in the number of films truly goodies characters became Whites (Gentlemen Officers: Save the Emperor, Admiral, Sunstroke, Red Mountain). On the other hand in the Russian cinema of the period there were movies where with the same sympathy there were portrayed both White and Red characters (Isayev, The purple colour of snow, Eye for an eye, Wolf Sun).

\section{References:}

1. Assmann, J. (2004). Cultural memory. Moscow: Languages Slavic culture, 368 p.

2. Bagdasarian, V.E. (2003). The image of the enemy in historical films 1930-1940-ies. National History. № 6, 32-46. 
3. Barsenkov, A.S., Vdovin, A.I. (2005). Russian history. 1918-2004. Moscow: Aspect Press.

4. Berger, P., Luckmann, T. (1995). The Social Construction of Reality. A treatise on the sociology of knowledge. Moscow.

5. Bezruk, M. (2014). Sunstroke: Bad anecdote. Tribune. 11/16/2014. http://tribuna.ru/news/2014/11/16/55776/

6. Bogomolov, Y (2014). Sunstroke in the service of the anti-liberal propaganda. 10/12/2014. http://www.echo.msk.ru/blog/bogomolov_y/1416986-echo/

7. Bykov, D. (2014). Hard breath. Profile. 10/10/2014. https://ruru.facebook.com/BykovDmitriyLvovich/posts/841875235856637

8. Chernova, N.V. (2007). Generalship image of Stalin during the Civil War in the treatment of Soviet cinema art of the second half of the 1930s - early 1950s. Ph.D. Dis. Magnitogorsk, p.27.

9. Danilova, E. (2014). There are no ready answers. There is no right or wrong. On the screens of the country a new film by Nikita Mikhalkov appeared - Sunstroke accoring Bunin. Spark. 2014. № 40, p.40. http://www.kommersant.ru/doc/2583718VP

10. Dolin, A. (2014). Mikhalkov. Abstracts. 08/10/2014. https://www.facebook.com /adolin3/posts/10204176005176576GE

11. Eco, U. (1976). A Theory of Semiotics. Bloomington: Indiana University Press.

12. Eco, U. (1998). Lack of structure. Introduction to semiology. St. Petersburg: Petropolis, $432 \mathrm{p}$.

13. Eco, U. (2005). The role of the reader. Studies on the semiotics of the text. St. Petersburg: The Symposium, 502 p.

14. Fedorov A.V. (2015). Transformation of Russian image in the West the screen. Moscow: Information for All, 2015. 221 p.

15. Fedorov, A.V. (2008). Analysis of the cultural mythology of media texts in the classroom at the student audience. Innovations in education. № 4, 60-80.

16. Fedorov, A.V. (2012). Analysis of audiovisual media texts. Moscow, $182 \mathrm{p}$.

17. Fomin V.I. (1980). Event and character in the adventure film. Adventure film. Ways and searches. Moscow, 24-38.

18. From the history of the Civil War in the USSR. Moscow, 1961.

19. Gireiev, I. (2014). Bunin motives. Your leisure. 09/10/2014. http://www.vashdosug.ru/ cinema/movie/551046/tab-reviews/review74524/

20. Gladilschikov, Y. (2014). Why Mikhalkov needed Bunin. Forbes. 9.10.2014., Http://stengazeta.net/?p=10041411.

21. Gunther, H. (2000). Archetypes of Soviet Socialist Realism. Socialist Realism Canon. St.Petersburg, 743-784.

22. Haknazarov, E. (2005). 89 circles of hell, Sunstroke by Nikita Mikhalkov. Fontanka.ru. 10/11/2014. http://calendar.fontanka.ru/articles/1848/

23. Halbwachs, M. (2005). The collective and historical memory. Emergency ration, № 2$3,40-41$.

24. Halbwachs, M. (2007). Social frameworks of memory. Moscow.

25. Hobsbawm E. (2000). Introduction: Inventing Traditions. In: Hobsbawm, E. and Ranger, T (Eds.) The Invention of Tradition. Cambridge, 2000, 1-14. oficerik

26. Ivanov, B. (2014). Mr. little officer // Film.ru. http://www.film.ru/articles/gospodin-

27. Kara-Murza, S.G. (2003). The Civil War (1918-1921). The lesson for the XXI century. Moscow: Exmo, 384 p.

28. Keen, S. (1986). Faces of the Enemy. San Francisco: Harper and Row.

29. Kenez, P. (2007). Red Attack, White resistance. 1918-1918. Moscow: Center Poligraf, $287 \mathrm{p}$.

30. Kirmel, N.S. (2008). White Guard intelligence services in the Civil War. 19181924 years. Moscow: Kuchkovo Field, 512 p.

31. Kichin, V. (2014). Kick to the solar plexus of Bunin. 10/10/2014. http://valerykichin.livejournal.com/488564.html 
32. Kondakov, Y.E. (2015). Civil War on the screen. White Movement: a tutorial. St. Petersburg: Elexis, 362 p.

33. Kudryavtsev, S.V. (2014). The worst in Sunstroke - is Sunstroke! 05/11/2014. http://kinanet.livejournal.com/3497539.html

34. Kulanin, R. (2015). Much ado about nothing. 01/30/2015. https://afisha.mail.ru/ cinema /movies/812117_leviafan/\#review

35. Levkievskaya, E.E. (2000). Russian idea in the context of mythological models and mechanisms of their sacralization // Myths and Mythology in Modern Russia. Moscow: AIRO-XX, 61-62.

36. Lotman, Y.M. (1999). Inside minded worlds. Man - the text - the semiotic sphere history. Moscow.

37. Malkova, L.Y. (1995). The face of the enemy. Cinema: Politics and people (1930s). Moscow: Mainland.

38. Maslova, L. (2014). For the Motherland, for the old. Komersant. № 185. 13.10.2014. C.14. http://kommersant.ru/doc/2588555

39. Matizen, V. (2014). Sun is in the apoplexy. Novye Izvestia. 10/13/2014. http://www.newizv.ru/culture/2014-10-13/208881-solnce-v-apopleksicheskom-udare.html

40. Mikhalkovich, V.I. (1980). When the hero becomes another. Adventure film. Ways and searches. Moscow, 16-23.

41. Moskvina. T. (2014). Sunstroke by Nikita Mikhalkov. The Hollywood Reporter. 02/10/2014. http://thr.ru/features/5081

42. Nekludov, S.Y. (2000). Structure and function of myth. Myths and Mythology in Modern Russia. Moscow: AIRO-XX, 17-38.

43. Ometsinskaya, E. (2014). Someone has to pull up the bell-ringer. SK-news. № 10, p.12.

44. Pavluchik, L. (2014). Sunstroke or a solar eclipse? Trud. № 144. 14.10.2014. http://www.trud.ru/index.php/article/14-10-

14/1318473_solnechnyj_udar_ili_solnechnoe_zatmenie.html

45. Petrovskaya, I.E. (2009). Stirlitz is so young, but Kolchak is just ahead. http://yarcenter.ru/content/view/25293/168/ 03.11.2009.

46. Pihoya, R.G. (2002). Historical memory: a case study through the eyes of a historian // National History. № 3, .201-202.

47. Plakhov, A. (2014). Russia is about both ways. Kommersant. 2014 (b). № 187. 15.10.2014, p.14. http://www.kommersant.ru/doc/2589474

48. Polyakov, Y. (1992). Civil War: the emergence and escalation. National History. № 6.

49. Razlogov, K.E. (2004). Specifics of feature films as a historical source. The history of the country. History of Cinema. Moscow, p.30.

50. Razzakov, F. (2008). It is the revenge of losers. About the film "Admiral", and not only. Soviet.Russia.http://www.sovross.ru/modules.php?name $=$ News\&file $=$ print\&sid $=4109$

51. Ricoeur, P. (2004). Memory, history, oblivion. Moscow.

52. Rutkovski, V. Mikhalkov's Time: 8 reasons to watch Sunstroke. Snob. 10/13/2014. http://snob.ru/selected/entry/82207?preview=print

53. Shambarov, V.E. (2002). White Guard. Moscow: Eksmo-Press.

54. Silverblatt, A. (2001). Media Literacy. Westport, Connecticut - London: Praeger, 449 p.

55. Slobodin, V.P. (1996). White movement during the Russian Civil War (1918-1924). Moscow: Moscow Law Institute.

56. Small, M. (1980). Hollywood and Teaching About Russian-American Relations. Film and History, N 10, p.1-8.

57. Smirnov, I. (2008). Admiral: procession from her husband for her lover. Skepticism. http://scepsis.ru/library/id_2218.html

58. Sokolov, A.K. (1999). The course of Soviet history, 1918-194O. Moscow: Higher School.

59. Solntseva, A. (2014). White-red war with yellow-blue lining. Novaya Gazeta. № 114 . 10.10.2014. http://www.novayagazeta.ru/arts/65627.html

60. Stishova, E. (2014). How did this happen? 10/13/2014. http://kinoart.ru/blogs/kakvse-eto-sluchilos

61. Strada M. (1989). A Half Century of American Cinematic Imagery: Hollywood's Portrayal of Russian Characters, 1933-1988. Coexistence, N 26, p.333-350. 
62. Strada, M.J. and Troper, H.R. (1997). Friend or Foe? Russian in American Film and Foreign Policy. Lanham, Md., \& London: The Scarecrow Press, 255 p.

63. Strizhenov, O.A. (2001). Confession. Moscow, 21, 90.

64. Taylor, R. and Spring, D. (Eds.) (1993). Stalinism and Soviet Cinema. London and New York: Routledge, p.131-141.

65. Tolkunova, A. (2014). Blow Mikhalkov Music. True. № 20. http://www.newlookmedia.ru/?p=38774

66. Toshchenko, J.T. (2000). Historical consciousness and historical memory. Modern and Contemporary History. № 4, p.4.

67. Trofimenkov, M. (2015). Skeleton is in the suitcase // Kommersant Weekend. № 3. 30.01.2015. S. 18 http://kommersant.ru/doc/2650884?isSearch

68. Tsvetkov, V.G. (2000). White Movement in Russia. 1918-1924 years. Questions of history. № 7, 56-73.

69. Tyrkin, C. (2014). Very dark alleys. http://webcache.googleusercontent.com /search?q=cache:5CoFLJbadYoJ:gorodakterov.com.ua/article.php\%3Far_adr\%3Darticle3169860 $+\& \mathrm{~cd}=5 \& \mathrm{hl}=\mathrm{ru} \& \mathrm{ct}=\mathrm{clnk} \& \mathrm{gl}=\mathrm{ru}$

70. Tyrkin, S. (2015). Clinical portrait. Komsomolskaya Pravda. 01/13/2015. http://www.kp.ru/daily/26235.7/3117203/

71. Vladimirov, S. (2014). Sunstroke by Mikhalkov - a film-pilgrimage. Komsomolskaya Pravda. 13.01. 2014. http://www.kp.ru/daily/26294.5/3172010/

72. Volkov E.V. (2009). White movement in the cultural memory of Soviet society: the evolution of "enemy image". Ph.D. Dis.. Chelyabinsk.

73. Volkov, E.V. (2008). White movement in the cultural memory of Soviet society: the evolution of the image of the enemy in feature films. http://orenbkazak.narod.ru/kino.doc

74. Volkov, E.V. (2013). Kolchak in the Soviet feature films. New Historical Journal. № 35.

75. Yampolskaya, E. (2014). There is some sun in cold water. Culture. 10/10/2014. http://portal-kultura.ru/articles/cinema/64168-nemnogo-solntsa-v-kholodnoy-

vode/?print=Y\&CODE=64168-nemnogo-solntsa-v-kholodnoy-vode

76. Zabaluev, Y. (2014). Treason and Homeland // Gazeta.ru. 07/10/2014. http://www.gazeta.ru/culture/2014/10/o7/a_6253261.shtml

77. Zelvensky, S. (2014). Sunstroke by Nikita Mikhalkov. Afisha.ru 09/10/2014. http://vozduh.afisha.ru/cinema/solnechnyy-udar-nikity-mihalkova-ona-utonula/.

78. Zimin, V.D. (2006). White matter rebellious Russia: Political regimes of civil war of 1918-1920. Moscow: Russian University of Humanity.

\section{УДК 37}

\section{Образ Белого движения в российском кино. Характеристика на современном этапе (1992-2016 гг.)}

Александр Федоров

Таганрогский педагогический институт им. Чехова, филиал Ростовского государственного экономического университета, Российская Федерация Доктор педагогических наук, профессор

E-mail: mediashkola@rambler.ru

Аннотация. Статья предоставляет возможность провести герменевтический анализ по теме белого движения в отражении российского кино на современном этапе (1992-2016 гг.). Данный герменевтический анализ предполагает постижение медиатекста через сопоставление с исторической, культурной традицией и действительностью; проникновение в его логику; через сопоставление медийных образов в историко-культурном контексте, сочетая исторический, герменевтический анализ структурных, сюжетных, этических, идеологических, иконографических / визуальных, СМИ стереотипов и анализ медиатекста, содержащего символы. Анализ такого рода медиатекстов, на наш взгляд, имеет 
особенно важное значение для медиа-грамотности будущих историков, культурологов, искусствоведов, социологов, психологов и педагогов. Таким образом, сравнительный анализ схем сюжета, персонажей и идеологии российских художественных фильмов 1992-2016 гг., в той или иной степени затрагивающих тематику Белого движения, приводит к выводу о существенном сходстве их медийных стереотипов. Контент-анализ СМИ экран тексты 1992-2016 гг. на тему, связанную с белым движением, как правило, позволяет представить их основные повествовательные схемы.

Ключевые слова: белое движение, русское кино, фильмы, герменевтический анализ, Россия, киноведение, медиатексты, медиаграмотность. 